\title{
重症心身障碍児者施設における空間構成と生活様態の関係についての考察 A CONSIDERATION ON BETWEEN SPATIAL COMPOSITION AND LIVING ASPECTS IN THE SEVERE MOTOR AND INTELLECTUAL DISABILITIES FACILITIES
}

\author{
古賀政好*, 山田あすか**
}

\author{
Masayoshi KOGA and Asuka YAMADA
}

\begin{abstract}
This paper aims to clarify the relationships between the spatial composition (such as presence and that layout of bedrooms, dayroom, lavatory and so on) and the residents' living aspects (staying places, ambulation, implication of staff etc.) in the severe motor and intellectual disabilities facilities with nursing home with small group units.

In the result, if the place used is concluded in livelihood in the unit, livelihood is concluded in the unit. It has the possibility to bring the cooped-up feeling simultaneously with stability. On the other hand, if the livelihood domain was wide, the tendency with low relations density with the staff was seen though there were a lot of stable stay places.

These differences are not the discussions that either is excellent as the spatial composition. I think that it means an advantage or a disadvantageous point is generated in each spatial composition.
\end{abstract}

Keywords : severe motor and intellectual disabilities facilities, spatial composition, living aspects, staying places, ambulation, communication, implication of staff

重症心身障碍児者施設，空間構成，生活様態，滞在場所，移動，コミュニケーション，職員との関わり

\section{1. 研究の背景と目的}

\section{1 社会的背景}

重症心身障碍児者（以下，重症児者とする）施設とは，児童福祉 法第 43 条において, 「重度の知的障害及び重度の肢体不自由が重複 している児童を入所させて，これを保護するとともに，治療及び日 常生活の指導をすることを目的とする施設とする.」と規定されて いる児童福祉施設である。児童施設の対象者は一般に 18 歳までだ が，重症児者は他に受け皿となる施設がないなどの理由により，年 齢の制限なく入居が可能である。また，重症児者施設は，福祉施設 であると同時に医療法に規定される病院としての機能も併せ持って いる。このため，重症児者施設においては，「医療・教育・生活」領 域それぞれに対応する設備・専門職を置き，これらの領域でのケア を互いに連携させつつ施設居住者の援助・療育を行う。また，多く の施設で, 地域で暮らす重症児者のための通所部門や相談部門, 訪 問介護・看護部門を設けるなどして，地域支援も行っている。

近年，障碍者施設全般の傾向として，「脱施設」と称される施設の 小規模化（グループホームなど）や，訪問介護・看護の充実によっ て障碍者の生活が地域に移行されるよう様々な取り組みが行われて いる. しかし，重症児者施設で暮ら寸居住者は，次第に症状が重く なり，施設全体では年を経るごとに医療ニーズが高まる状況にある. また現在住宅で暮ら寸重症児者についても，核家族化や保護者の高 齢化などによって家族介護力の継続に不安を抱える事例は増してお
り, 地域での受け血が充分でないことも相まって, 施設への入所を 希望しながら待機状態である入所希望者数には減少の兆しがない. 脱施設の思想が実現されることは望まれるものの, 戦後に建てられ た重症児者施設の建て替え時期を迎え, 現実問題としてこうした施 設の建築的あり方が問われなければならない. 今後は, 介護・看護 から「生活」そのものへと建築空間の目的を転換した施設計画を考 える必要があろう。

\section{2 理論的背景}

重症児者施設についての研究は多くないが，いくつかの既往研究 がある，例えば，山脇ら ${ }^{1 ）}{ }^{2)}$ は，重症児者の自己決定的な生活には 「移動能力」と「コミュニケーション能力」が重要であると述べ, 重 症児者の生活には本人の属性条件が大きく影響することを指摘して いる，また，重症児者施設では，居住者の生活の質を向上させるこ となどを目指して, ソフト・ハードの両面から生活単位の小規模化 が試みられている。これに関して, 生活単位の小規模化が居住者の 生活に与える影響についての関連研究として, 筆者ら ${ }^{3)}$ はグループ リビング型知的障碍者入所更生施設をフィールドとして, 居住者の 居室やユニット内共用空間の設えや利用のされ方が居住者個々人の 障碍の特徴に応じて異なることを示している．また，生活単位の小 規模化が進んでいる高齢者居住施設を対象とした研究4 6) では, 生 活単位の小規模化が居住者の会話交流やスタッフの関わり方, 滞在 場所に影響することなどが明らかにされている，さらに，拙稿：小

\footnotetext{
本稿は，筆者・古賀政好の平成19年度立命館大学理工学部建築都市デザイン学科卒業論文に大幅な加筆・修正を加えたものである。

* 立命館大学大学院理工学研究科 修士課程

** 立命館大学理工学部建築都市デザイン学科

Master's Program of Graduate School of Science and Eng., Ritsumeikan Univ.

講師・博士 (工学)

Lecturer, Department of Architecture and Urban Design, College of Science and

Engineering, Ritsumeikan University, Dr. Eng.
} 
規模生活単位が法制度化されている特別養護老人ホームについての 研究のなかで，ユニットの完結性が高まることで，居住者の生活に 安定がもたらされる一方, 人間関係や活動範囲の縮小がもたらされ, 課題となる場合があることを指摘している7).

\section{3 研究の目的}

以上のように, 高齢者施設では生活単位の小規模化による居住者 の生活への影響について明らかにされているが，重症児者施設にお いてはこうした小規模な生活単位での空間構成のあり方が居住者の 生活に実際にどのような影響を与えるかについて，充分な検証がな されていない，本稿では，今後も必要とされるであろう重症児者施 設を対象として，異なる空間構成（寝室・デイルーム・トイレなど の個々の空間の有無と, その配置) をもつ小規模生活単位 (ユニット) 型療育を実施している施設での, 滞在場所と移動, 職員との関わり といった居住者の生活様態の比較を通して, 空間構成が居住者の生 活様態にどのような影響を与えるのかを具体的に明らかにすること を目的とする.

なお本稿では, 居住者の生活様態について, 特に居住者の滞在場 所（生活のなかで時間を過ごす場所）と移動頻度, 職員との関わり に着目する。

\section{2. 調査の概要}

\section{1 調査対象施設の概要}

従来の大規模生活型施設においては，多くの重症児者が一斉・一 括的に処遇され，個々人に向かい合った介護・看護が成立しにくい と批判される。しかし，重症児者施設でユニット型療育を行ってい る施設は多く存在しないのが現状である注 1 )。本稿の調查対象施設 には，重症児者施設において，先駆的事例としてユニット型療育を 行っている 2 施設 $\mathrm{BK} ・ \mathrm{BY}$ 注 2 ) を選定する（表 1 ）。両施設は同一法 人によって運営されており, 職員配置や運営方針には大きな違いが ないが，施設の建築面での条件に差異がある. 居住者の生活様態に は，施設の建築空間のあり方とともに，職員配置，理念等の運営の あり方が影響を及ぼすと考えられる，BK・BY では，運営に大きな 差異がないため両施設における居住者の生活様態の比較をすること で，より建築空間による影響を明らかにしや寸いと考えた。

この 2 施設では，施設全体はいくつかの住棟によって構成され， それぞれの住棟がさらに少人数のユニットに分かれている．職員は 住棟によって固定されており, さらに担当のユニットが決まってい る注3). このなかで, 調查対象には調査の受け入れが可能で, かつ 空間構成の特徽が異なる住棟を選定した。 図 1 に各調查対象住棟の 特徴を示し, 図 2 にそれぞれの住棟の空間構成の違いをダイヤグラ ムで示した。

BK では, 第 3 住棟（居住者の特徵：身体障碍は重いが急変の可能 性が比較的少なく, 知的障碍は軽度から重度まで幅がある), BY では, 第 1 住棟（居住者の特徵：身体障碍と知的障碍はともに重度で常時 医療的ケアが必要であるが, 健康的には安定している) と, 第 2 住 棟（居住者の特徴：身体障碍と知的障碍はともに重度で常時医療的 ケアが必要である人と知的障碍は比較的軽度であるが身体障碍が重 度な人がいる）である。トイレ注4) は，BK では住棟内の各ユニット 内にある。一方, BY では住棟内にあるが各ユニット内にはない。こ
表 1 調查対象施設概要

\begin{tabular}{|c|c|c|}
\hline 名称 & BK & BY \\
\hline 施設区分 & \multicolumn{2}{|c|}{ 重症心身障碍児施設 } \\
\hline 所在地 & 滋賀県草津市 & 滋賀県野洲市 \\
\hline 運営主体 & 社会福祉法人 & 社会福祉法人 \\
\hline 入居定数 & 108人 & 138 人 \\
\hline 職員数 & 101人 & 124人 \\
\hline 敷地面積 & $23,336.27 \mathrm{~m}^{2}$ & $36,241.75 \mathrm{~m}^{2}$ \\
\hline 延床面積 & $6.731 .06 \mathrm{~m}^{2}$ & $9,396.11 \mathrm{~m}$ \\
\hline 併設施設 - & $\begin{array}{l}\text { 養護学校, 地域交 } \\
\end{array}$ & $\begin{array}{l}\text { 養護学校, 通園棟 } \\
\text { など } \\
\end{array}$ \\
\hline 空間特徵 & $\begin{array}{l}\text { トイし・食堂がユ } \\
\text { ニットトる. }\end{array}$ & $\begin{array}{l}\text { トイし・食堂がユ } \\
\text { ニット外にある. }\end{array}$ \\
\hline
\end{tabular}

表 2 グループの居住者の 属性の特徵

\begin{tabular}{|c|c|}
\hline 5ルーフ & \begin{tabular}{|l} 
特徵 \\
\end{tabular} \\
\hline$B K-R$ & 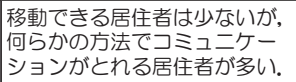 \\
\hline$B K-G$ & $\begin{array}{l}\text { 移動できる居住者は半数いるが } \\
\text { 知的障碍が重い居住者が多い. }\end{array}$ \\
\hline$B Y-Y$ & $\begin{array}{l}\text { 移動できる居住者は半数いるが } \\
\text { 知的障碍が重い居住者が多い. }\end{array}$ \\
\hline BY-I & $\begin{array}{l}\text { なんらかの方法で移動し, コ } \\
\text { ミュニケージン住 } \\
\text { 者が多い. }\end{array}$ \\
\hline
\end{tabular}
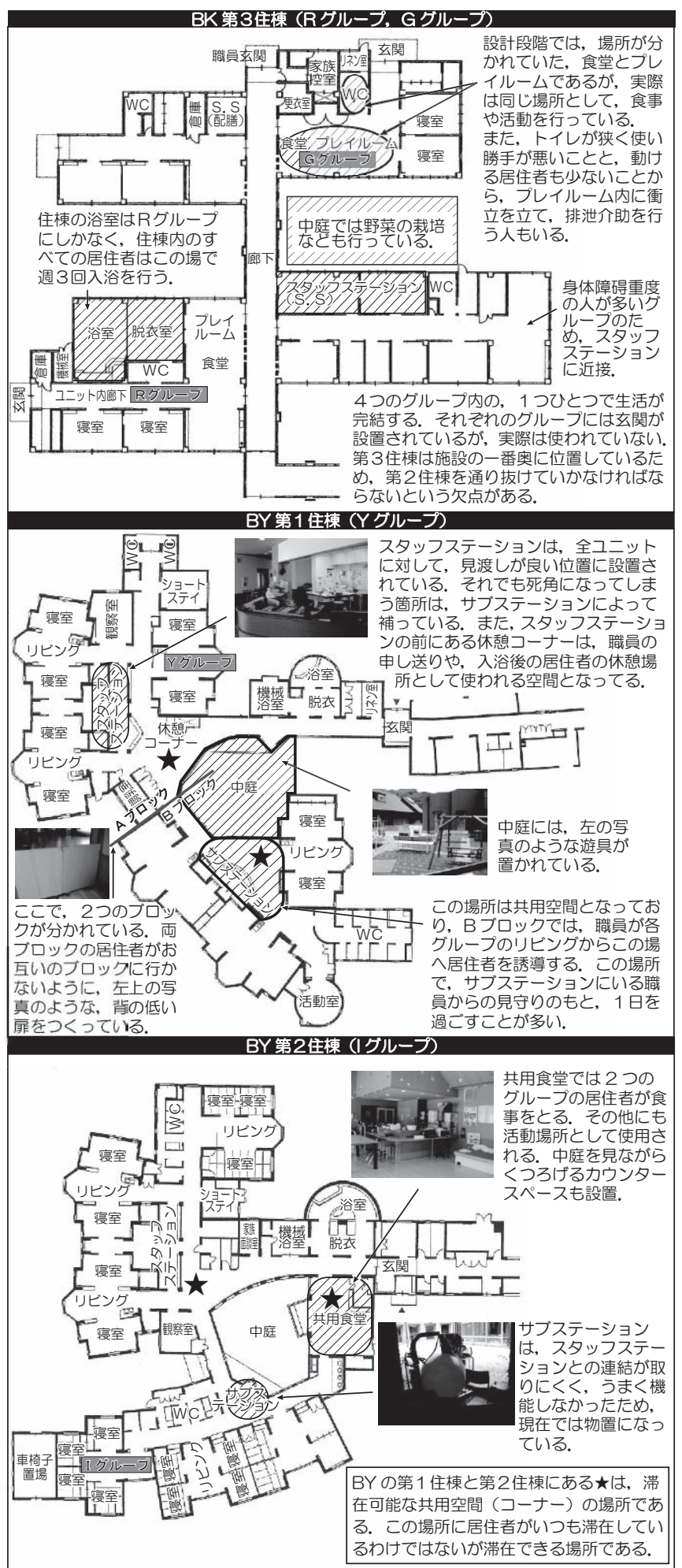

図 1 調查対象住棟の特徵 


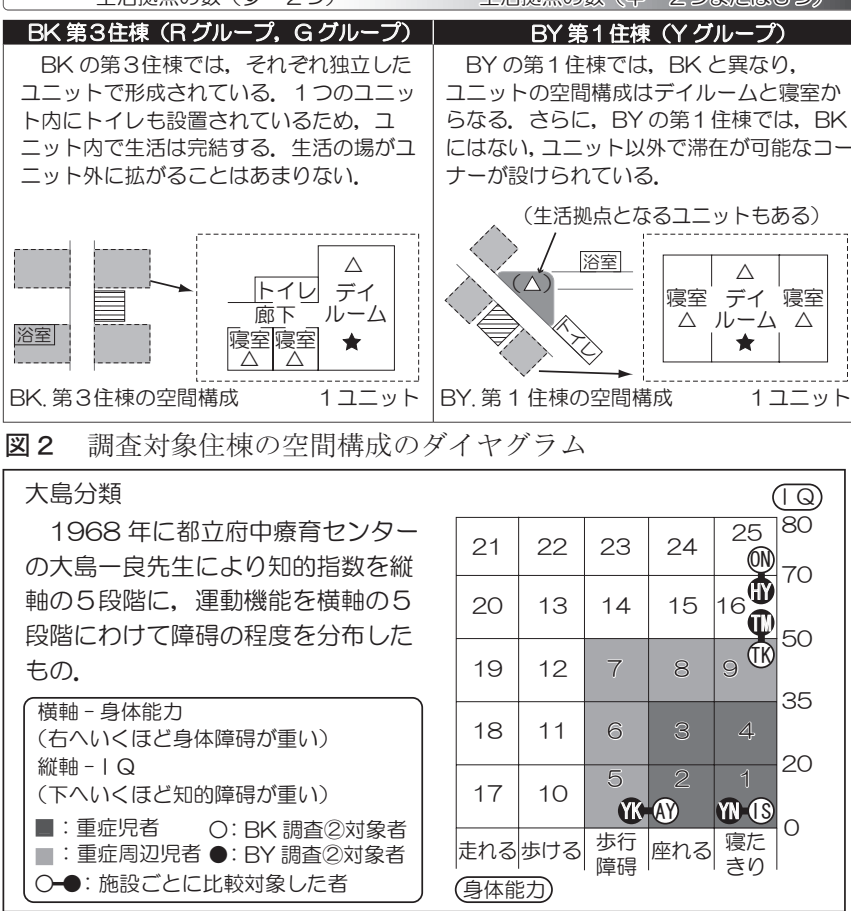

図 3 大島分類でみる選定調査対象者の状況

のため BK の日常生活圈域はユニットのなかで完結しうるという意味 でBY より小さいといえる。 また，BYでは，コーナーや共用食堂注5) など住棟のなかにユニット外の場所で滞在場所となりうるスペース が設けられており，またトイレなどの日常生活行動注 6) に伴ってユ ニット外に出る機会があることから, BK より場所選択性があるとい える. よって, BK と BYでは 2 ユニットの完結性が異なる。ささらに BY の中で, 食事場所の違(注7)により, BY の第 1 住棟と BY の第 2 住棟との生活拠点の数も異なっている.

本稿の分析・考察においては，ユニット内の空間構成やユニット 外の共用空間の有無の違いにより，BK と BY の空間構成が大きく異 なることを前提に施設間の比較を行う。ささらに, BY の第 1 住棟と BY の第 2 住棟のユニット外の共用食堂の有無による生活拠点の数の違 いにより，もたらされると考えられる生活様態の違いが顕著である 場合，その空間構成についても比較し，分析・考察を行う.

なお，ユニット内の共用空間を，BKではプレイルーム（食堂兼）， BY ではリビングと呼称しており，それぞれ生活空間として異なる位 置づけを与えようとの意図が推察されたが，実際にはそうした相違 を見出すことができなかったため, 双方を「デイルーム」と呼称する.

\section{2 調査方法}

調査に際しては, 調查対象者の行動に影響を与えないように十分 考慮した上で, 調查者がユニット内に常駐する観察調查を行った. また, 観察調查に先だって, 各施設に実習生として滞在し, 生活の 実態・流れの全体像を把握するとともに, 個々の居住者の障碍の種 類や程度，生活習慣を把握した。観察調査は以下の 2 つ調査から なる。

(1)各施設 $2 つ$ づループの居住者について, 起床から就寝までの 10 分間隔での滞在場所調査

\section{BYの第2 住棟も，第1住棟と同㥞にユニ}

トの空間構成はデイルームと葠室からなる.

また, スタッフステーションに近接してコーナー

も設けられているが,「共用食堂」があるという 点でBYの第1 住棟とは空間構成が異なる.

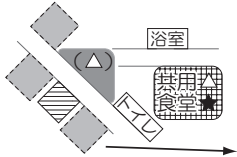

BY. 第2 住棟の空間構成

表 3 調查概要

\begin{tabular}{|c|c|}
\hline & 観察調查内容 \\
\hline (1)1日の生活で $\sigma$ & の滞在場所の把握 \\
\hline ・各施設 $2 \supset \sigma$ & のグループの起床から就寝までの 10 分ごとのプロット. \\
\hline (2)特定の調査対耇 & 象者と職員との関わり方の把握 \\
\hline $\begin{array}{l}\text { ・1)の調查対等 } \\
\text { 就誛までの, }\end{array}$ & $\begin{array}{l}\text { 象グループ内から2名ずつ, 計8名の調査対象者を選定し, 起床から } \\
\text {. 職員との関わりが生じた時間・内容・きっかけ・場所を記録. }\end{array}$ \\
\hline & $\begin{array}{c}\text { 調查刘象者 } \\
\end{array}$ \\
\hline $\begin{array}{l}\text { (1)の調查対象グル } \\
\text { BK : Rグルー }\end{array}$ & $\begin{array}{l}\text { ループ } \\
- \text {-プ, Gグループ-計 } 16 \text { 名, BY：Yグループ, । グループ - 計 } 16 \text { 名 }\end{array}$ \\
\hline $\begin{array}{l}\text { (2)の調査対象者 } \\
\text { コミュニケーシ } \\
\text { すうの計8名（颣 }\end{array}$ & $\begin{array}{l}\text { ション (可・不可) - 自力移動 (可·不可) の組み合わせで, 各施設4名 } \\
\text { 類型ごとに近似した者を調査刘象とする). }\end{array}$ \\
\hline & 調查日程 \\
\hline $\begin{aligned} & \text { BK }: \text { 実習（居 } \\
& \text { ・プし調查 } \\
& \text { ・本調查 } \\
&\end{aligned}$ & 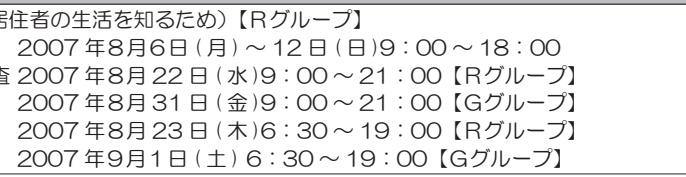 \\
\hline $\begin{array}{c}\text { BY : 実習【I } \\
\text { •本調查 }\end{array}$ & 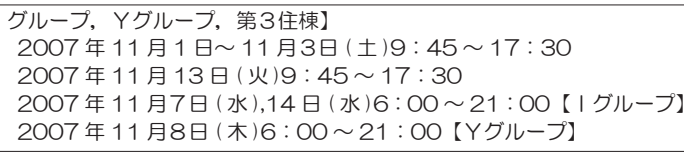 \\
\hline
\end{tabular}

(2)移動とコミュニケーションの能力注 8$)$ や障碍の程度に着目して 選定した調查対象者計 8 名注9) について, 終日の滞在場所, 行為内容, 職員との関わり状況に関する調査. 障碍の程度については全国の重 症児者施設で広く用いられている大島分類を参考にする（図 3 ).

なお，表 2 に各施設での調查対象グループに属する居住者の属性 の特徵を示し, 表 3 には詳細な調查概要を示している.

\section{3. 滞在場所・関わり · 移動の関係}

\section{1 滞在場所・職員との関わりの流れ}

図 4 は, 縦軸に滞在場所・横軸に時間をとり, 調查対象者の 1 日 の滞在場所と職員との関わり注 10) を示したものである. 対象住棟の 居住者全員の生活概況を把握した上で (図 7 ), 移動能力とコミュニ ケーション能力の組み合わせによって, 施設ごとに 4 名の居住者の 事例を示している. 図 4 から, 以下の特徴が読み取れる.

BK では，移動・コミュニケーションがともに可能である TK 以外 の 3 名が， $6 \sim 21$ 時の調查対象 15 時間中, 10 時間以上をデイルー ムで過ごしていることが特徴的である. 移動とコミュニケーション 能力が異なる, 個々の居住者別に作成した終日滞在場所を平面図に プロットした図からも, TK 以外の 3 名は多くの時間をデイルームで 過ごしており，ユニット外に出ることは極めて少ないことがわかる.

一方, BY では，居住者ごとに滞在場所が異なるが，これには対象 者とした居住者の住棟が異なり, 住棟ごとに空間の相違があること 


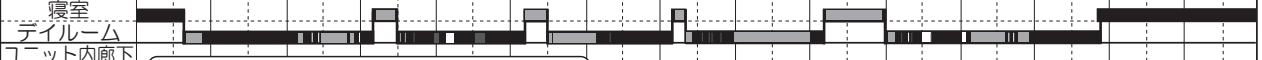

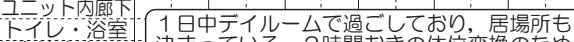

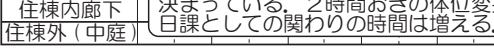

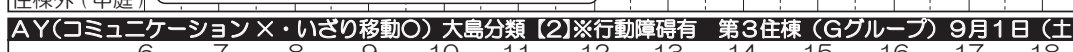

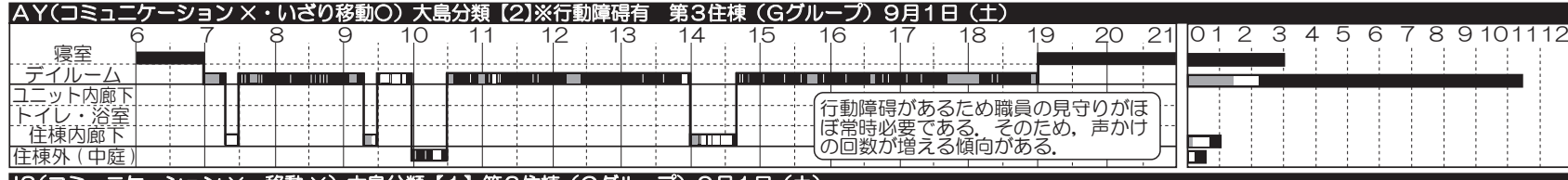

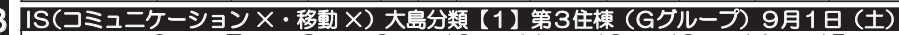
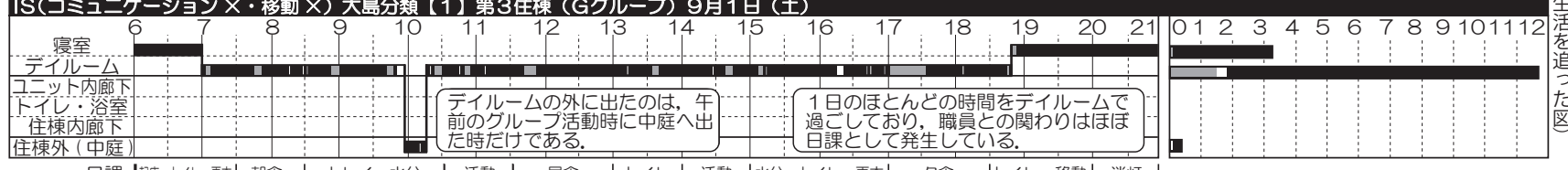

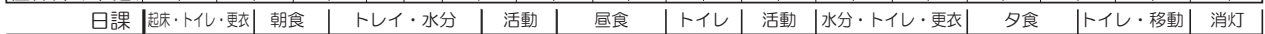
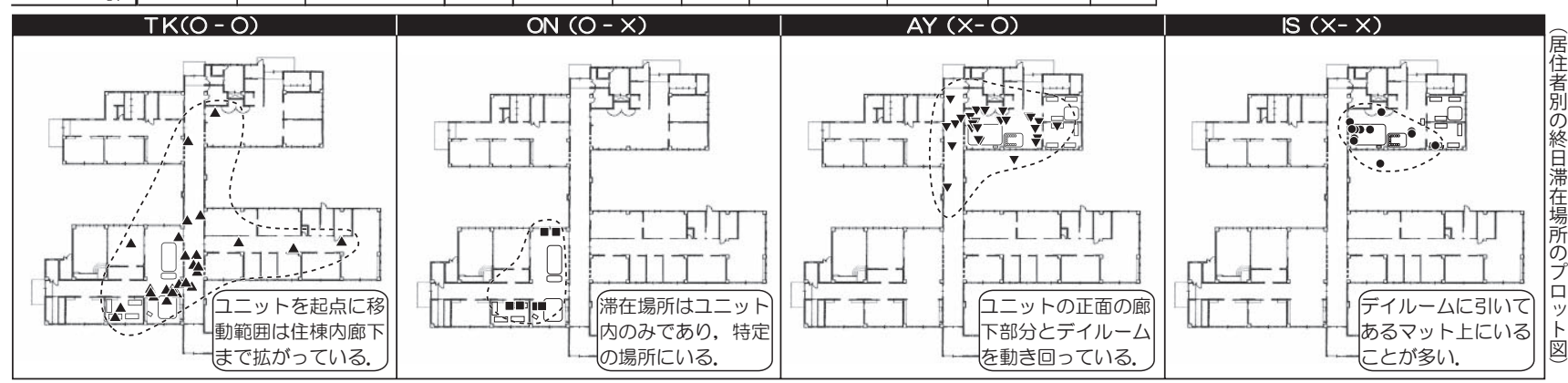

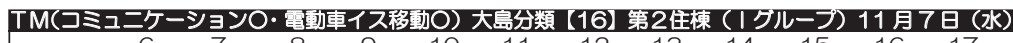

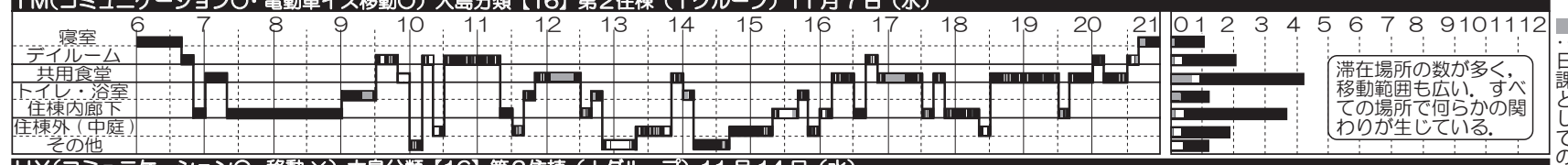

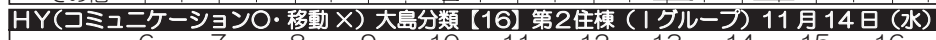

$\begin{array}{llllllllllllllll}16 & 17 & 18 & 19 & 20 & 21 & 0 & 1 & 2 & 3 & 4 & 5 & 6 & 7 & 8 & 9101112\end{array}$

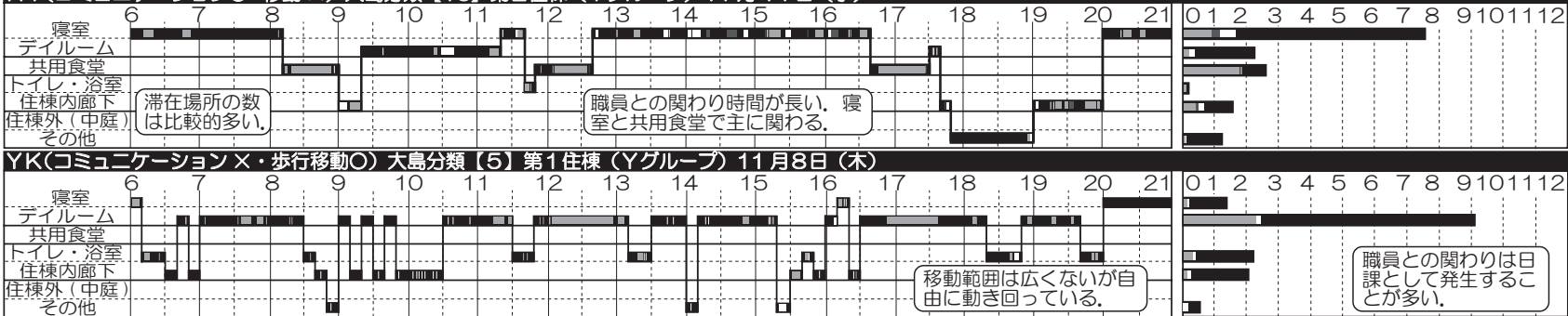

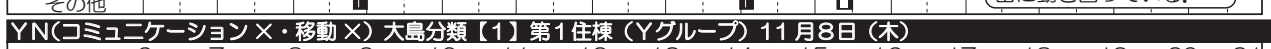
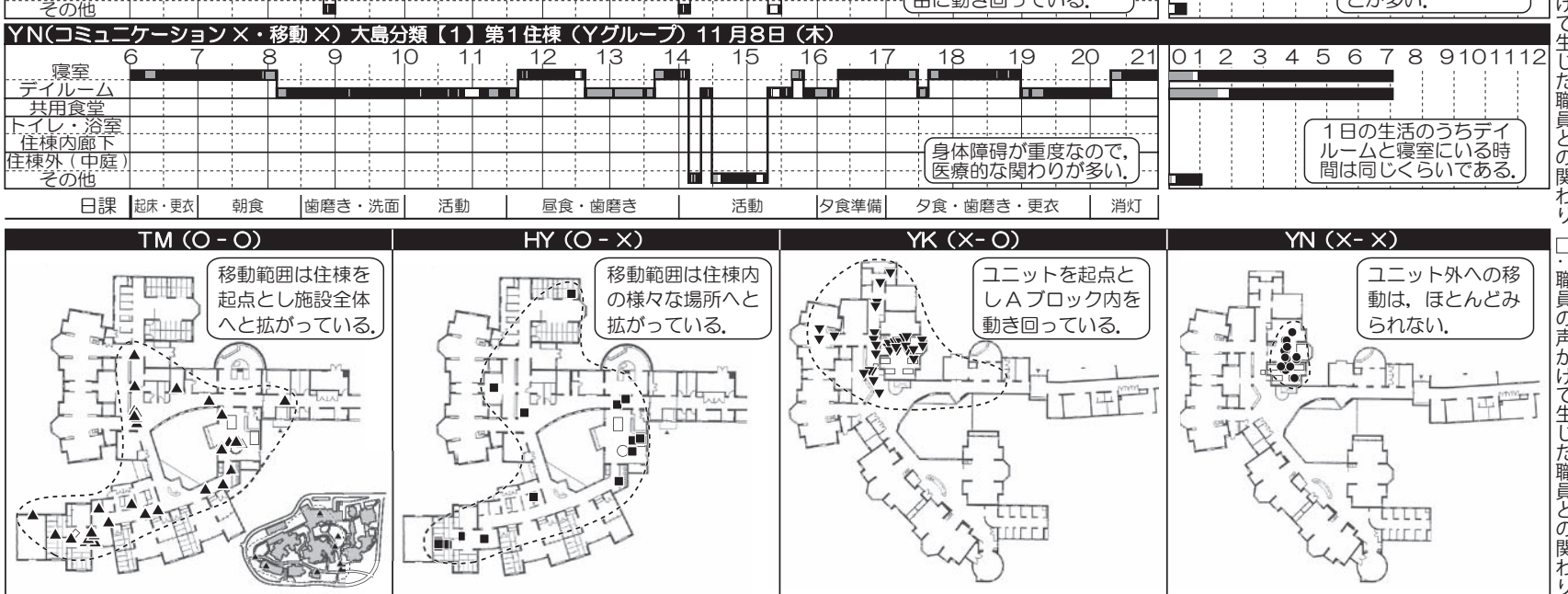

4 移動・コミュニケーション能力が異なる居住者の 1 日の滞在場所の変化と職員との関わり 
も影響していると考えられる．共用食堂のある第 2 住棟では, グルー プによって，食事の度に共用食堂へ移動するため，共用食堂のない 第 1 住棟よりも居住者の移動頻度や滞在場所数が多く, 場所別滞在 割合が異なる．移動・コミュニケーションともに可能な TM 以外の 3 名の居住者は，寝室またはデイルームでの滞在時間が 7 時間以上で, TM に比べてユニット外での滞在時間が短い傾向が顕著である.

日課での職員との関わりに着目すると，TM と HY は共用食堂，YK と YN はデイルームでの関わり時間が最も長い。両施設とも, BY の TM を除いて，すべての居住者がデイルームで 1 日の多くの時間を過 ごしており，これらの場所が生活の起点となっていることが咞える. 職員との関わりもほとんどがデイルームで，日課をきっかけに生じ ることが多いことがわかる。

3.2 移動・コミュニケーション能力と移動頻度の関係

図 5 は，各施設 4 名の調查対象者について，移動とコミュニケー ション能力の組み合わせによって, 移動頻度注 11) を比較した図であ

る.ロの大きさが，移動頻度の回数を示している．両施設を比較す ると，以下のことが指摘できる.

BK では，移動能力によらず移動頻度に差は小さい，ON（コミュニ ケーション○・移動 $\times$ ) の移動頻度が 10 回あるのは, 体位交換に伴っ て寝室とデイルームの行き来があったためである．IS(コミュニケー ションメ・移動 $\times)$ は移動頻度が 4 回と少なく, 同じ空間に長時間 滞在していることがわかる，一方 BY では，自力移動ができるか否か によって移動頻度の差が大きく，2 倍以上の開きがあることが読み 取れる．HY（コミュニケーション○・移動X）は，主に「寝室・デ イルーム・共用食堂」間の移動であるが, YN（コミュニケーション $\times$ ・ 移動 $\times$ ）は，主に「寝室・リビング」間の移動であり，移動回数は 同数程度であるが滞在場所や移動距離などの内容は異なる.

以上のことから，移動頻度に関して次の 2 点のことがわかる.

(1)移動頻度にはコミュニケーション能力はあまり影響せず，移動 能力に大きく影響される.

(2)施設によって，移動能力による移動頻度の差の大小が異なり， ユニット外での滞在場所がある事例では移動頻度の差が大きい注 12).

\section{4. 移動能力と 1 日の滞在場所の関係}

4. 1 ユニット全体の1日の滞在場所の移り変わりと滞在割合

図 6 は，図 4 を簡略化しユニットごとに居住者全員の 1 日の滞在 場所を示した図である. また図 7 に, 自力移動ができるか否かの別 ごとに, 調查対象者全員の 1 日の滞在場所を平面図へのプロットと 場所別滞在割合で示した。両図より, BKの 2 つのグループでは, 移 動可能者を含め， 1 日の多くの時間を寝室・デイルームで過ごすこ とがわかる. 一方, BKよりも場所選択性のある BY の 2 つのグルー プにおいては異なる滞在様態が観測された，Yグループでは，自力 移動が可能か否かによって滞在場所が大きく異なるが，I グループ においては，自力移動ができない居住者についても 1 日の滞在場所 の変化が頻繁に見られた。 これは，Iグループでは食事の度に滞在 場所をかえるためであると考えられる。

\section{2 移動頻度と空間利用の関係}

1) 空間利用数 居住者が 1 日の間に滞在した場所の数を「空間 利用数」と呼ぶこととし,この定義を図 8 に示す. 寝室, デイルーム, トイレの 3 箇所は，どの居住者であっても 1 日の間に利用すること が想定されるため, 空間利用の数が 3 ヶ所以内である場合を［少な い，４ヶ所以上の場合を [多い］と定義した．またこの図によると， BK と BY のYグループに属する移動不可能者では, 空間利用の数が 2 ヶ所か 3 ヶ所がほとんどであるが, BY のI グループでは, 移動不 可能者でも 4 个所・5 所と利用しており, 自力移動ができないか らといって利用空間の数が少ないわけではないことがわかる. 移動 可能者の空間利用数をみると, 全体に移動不可能者よりも多いこと が確認できる．また BYでは 5 ケ所・ 6 ケ所の割合が高く, BK では 移動できる居住者でも空間利用数が移動不可能者と大差なく, 生活

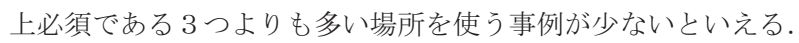

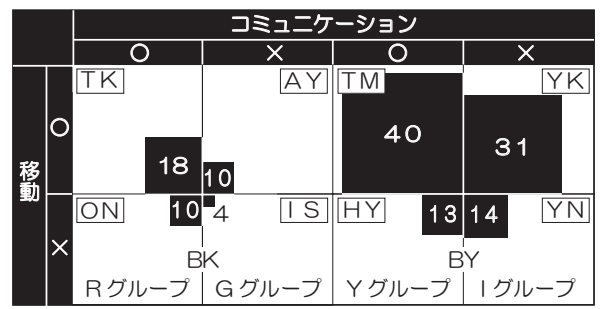

BKでは移動能力によ らず移動頻度に差が小さ い. 一方, BYでは移動 能力の有無によって, 移 動頻度の差が大きい.

移動頻度は, コミュニ ケーション能力にあまり 影響せず, 移動能力に影 響することがわかる.

図 5 能力別移動頻度年位：移動回数口内：対象者名)

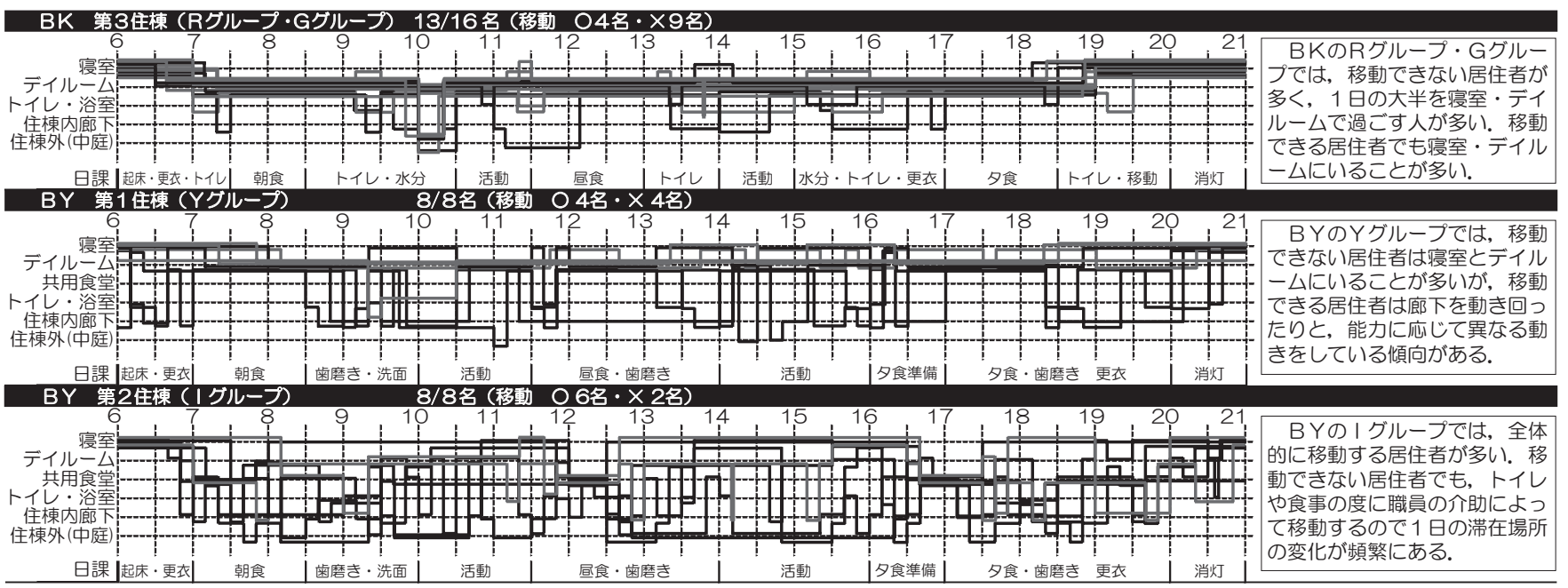

図 6 各グループの滞在場所の変化

：移動 $\square$ : 移動 $X$ 
2 ）同一空間内での移動頻度 次に, 滞在場所数が同じであって も, そのなかでの移動頻度, 寸なわち一つの空間のなかでの移動頻 度には相違があることから, 個々の居住者について一つひとつの滞 在場所内での移動回数を数え,「同一空間内での移動頻度」として, その定義を図 9 のように定めた。なおこの際，1人の居住者につい て, 最も移動頻度が多かった滞在場所での移動頻度を, その居住者 の「同一空間内での移動頻度」とした．さらに，同一空間内での移 動頻度が全体によ゙のように分布しているかを参考に, 移動頻度が 3 回以下を [少], 4〜6 回を [中], 7 回以上を [多] と定義した. 図 9 から, BK では移動能力によらず同一空間内での移動頻度 [中一 多］の居住者の割合が高い一方, BY では移動頻度 [少一中］の居住 者の割合が高いという相違がある.また, 移動可能な居住者では,
BK と BY で分布の傾向が明らかに異なり, BK ではすべての居住者の 移動頻度が 5 以上であるのに対し, BY では移動頻度 4 以下に分布し ている. 自力での移動ができない居住者については, 両施設とも [少 一多にに分布しており, 両施設での差は明らかではない.このこと から, 同一空間内での移動頻度から見たとき, 両施設の空間条件等 の相違は, 移動可能者にとってより影響が強いと指摘できる.

3 ) 空間利用数と同一空間内での移動頻度 以上の二つの定義を もとに，各居住者ごとに空間利用数と同一空間内での移動頻度の関 係をみると，図10のようになる。

$\mathrm{BK} \cdot \mathrm{BY}$ とも，移動不可能者は空間利用数が少ない場合には，同数 程度ずつ同一空間内での移動頻度 [少ー中〜多］に分布しているが， 移動不可能者で空間利用数が多い場合には, 同一空間内での移動頻

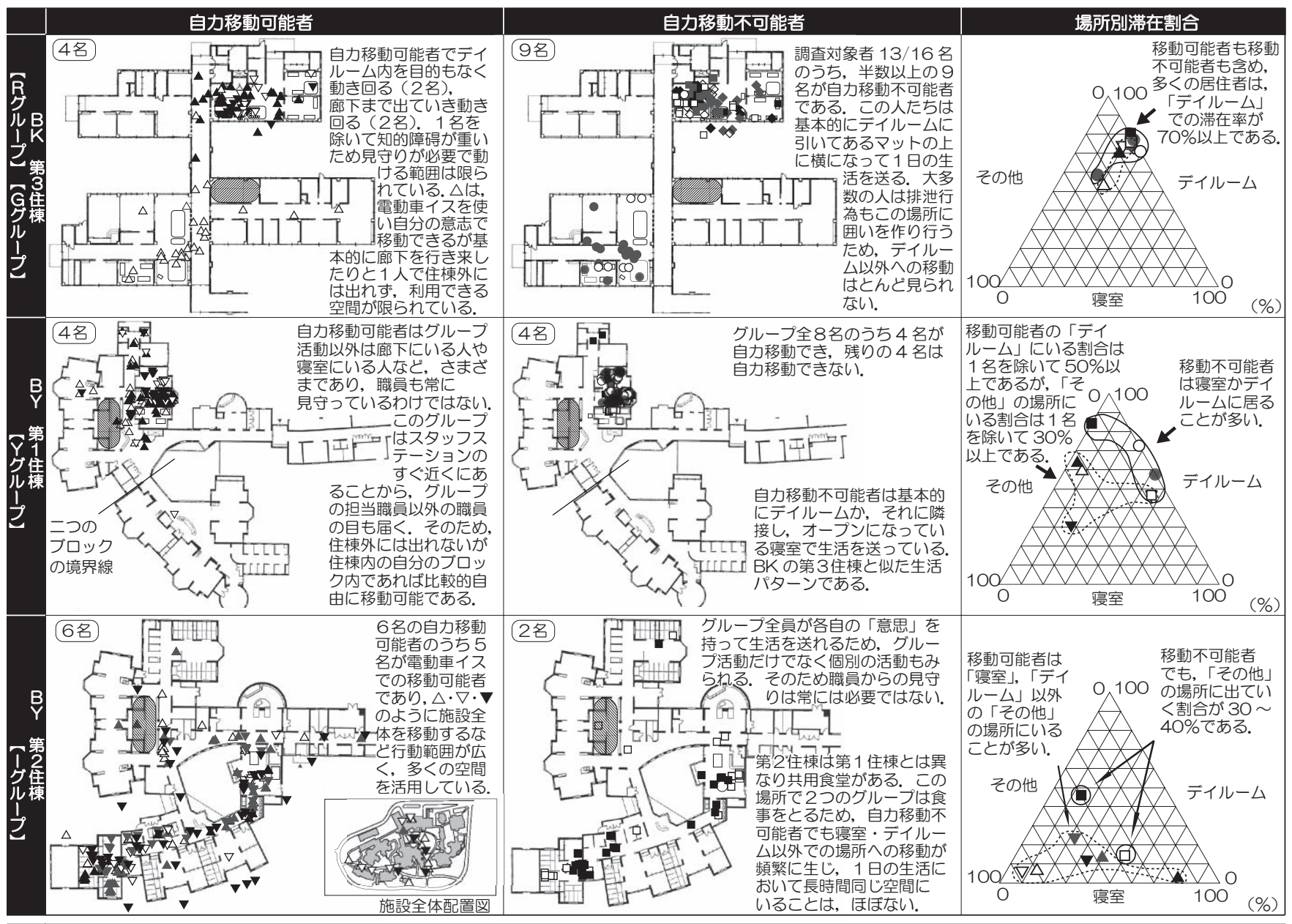

凡

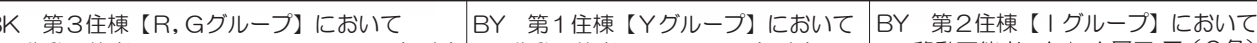

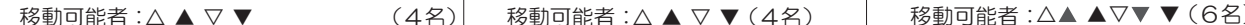

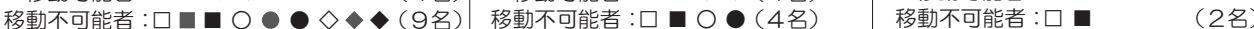

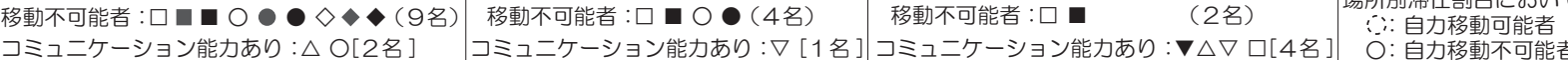
図 7 各グループ全体の移動能力別滞在場所分布・滞在割合

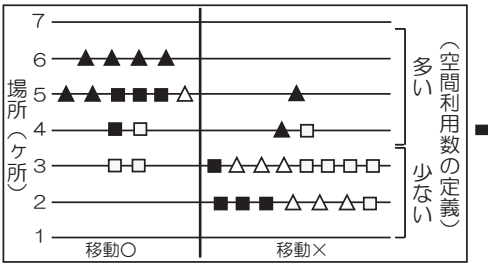

図 8 空間利用数の定義

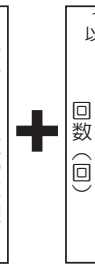

図 9 同一空間内での移動頻度の定義

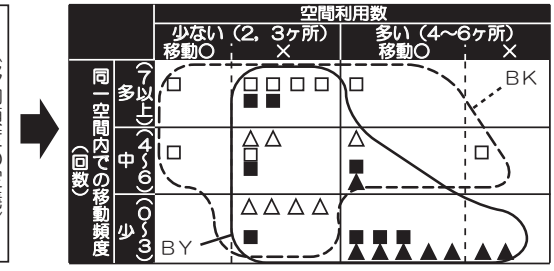

図 10 空間利用数と同一空間内での 移動頻度の関倸

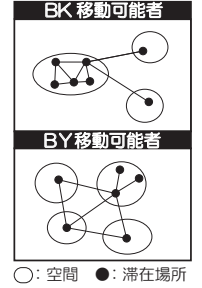

○: 空間・滞在場所 
度は［少一中］のみである. 自力移動ができない居住者にとって， 空間利用数が増えると同一空間内での移動頻度は減少する傾向にあ ることが指摘できる.

空間利用数と同一空間内での移動頻度の関係を, BK と BY で比較 すると, 両施設では分布の傾向が異なることに気づく. BKでは, 空 間利用数が少ないと同一空間内での移動頻度は「少〜中〜多」と分 布しているが，空間利用数が多いと同一空間内での移動頻度も多い 傾向がある（図上では右下が欠ける分布傾向を示す）。これに対して BY では, 空間利用数が少ない場合には同一空間内での移動頻度の分 布に偏りは顕著でないものの，空間利用数が多いと同一空間内での 移動頻度が多い居住者がいない（図上では右下がりの分布傾向また は右上が欠ける分布傾向を示す)，才なわち，一つの空間のなかで落 ち着かずに動きまわるような状態がなくなるため，一つの空間内で みたとき, 安定した滞在をしているといえる。両施設での分布には 明らかな相違が見られ, この要因として, 対象とした居住者属性や 運営方針に大きな相違がないことから，空間構成の相違と，これに 伴う生活展開の相違が影響しているものと推論される.

両施設での, 空間構成と生活展開の相違を踏まえて空間利用数と 同一空間内での移動頻度の関係について比較考察する. BKでは, 移 動不可能者の同一空間内での移動頻度は職員の誘導の回数によるた め, 居住者本人の意思というよりは介護・看護的視点からみた本人 の状態に応じて移動頻度が異なる. また, 同じ理由により, 見守り や介護がしやすいデイルームでの滞在時間が長くなり，ユニット外 の場所を含む様々な場所に行くことは少ない. 自力移動できない居 住者を含め, 空間利用数は全体に比較的少なく, 移動できる居住者 であっても同じ場所にずっと居続けるような生活展開となってい る.また少数の「動きたい」欲求のある居住者が長時間滞在するデ イルーム内で複数の場所を転々とすると同時に, ユニット外の場所 を含む複数の空間を利用するという構造にある. BY では, 移動可能
者が BKよりも多いためもあって比較的空間利用数が多い. 自力移動 ができない居住者は, 職員の誘導などによって同一空間内での移動 頻度に個々人で相違があるが, 移動可能者はユニット内のデイルー ムや寝室，共用空間の食堂などユニット外の空間を含む多くの空間 を利用し，かつそれぞれの空間内では移動をせず，安定的な滞在を している.このように両施設では, ことに移動可能者の空間利用数・ 同一空間内での移動頻度の関係に建築空間的な相違が影響している といえる.こうした差異が顕著に現れた例として, BY のI グループ が挙げられる. I グループ (身体障碍・知的障碍ともに比較的軽度 の居住者が多い) では, 全員の空間利用数が多く, 一名を除いて同 一空間での移動頻度が「少」であるのも特徴的である. 利用可能な 空間数に幅がある BY では, 身体・知的障碍が軽度である場合, 多く の場所を利用し, かつそれぞれの場所であまり複数回滞在場所を変 えることがなく, 空間同士の「移動」と空間内での「滞在」にメリ ハリがあるといえ，一つの空間内でみたときに安定的な滞在をする 傾向があるものと推察される.

\section{5. 居住者と職員との関わり}

\section{1 関わりの回数と関わり時間}

図 11 は 1 日を通しての職員と終日追跡調查の対象者計 8 名との 関わりを分類わけし，1回ごとの関わりについて, その継続時間を 示したものである. 総じて, [声かけ $]$ や [会話 ] に比べて [ 日課 ] での関わりは継続時間が長い関わりが多い傾向にあり, 関わりの継 続時間が，関わりの種類を反映しているといえる. 図 12 は, 調查対 象者の起床から就寝までの職員との関わり回数・時間である. 両施 設で，日課をきっかけとする職員との関わりが多いことが確認でき る. 身体障碍が重度の居住者は, 軽度の居住者に比べて医療的ケア などの必要度が増すため日課としての関わりが増える傾向がある. また，コミュニケーション能力がある居住者は自ら職員に思いを伝
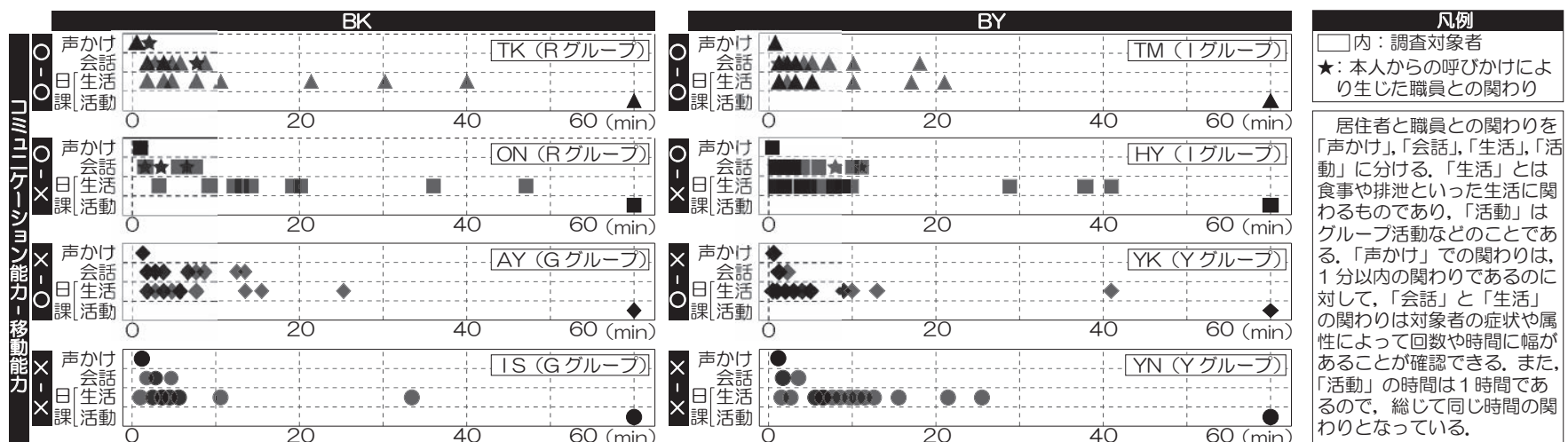

図 11 調査対象者の 1 日を通しての関わりの種類と時間の関係
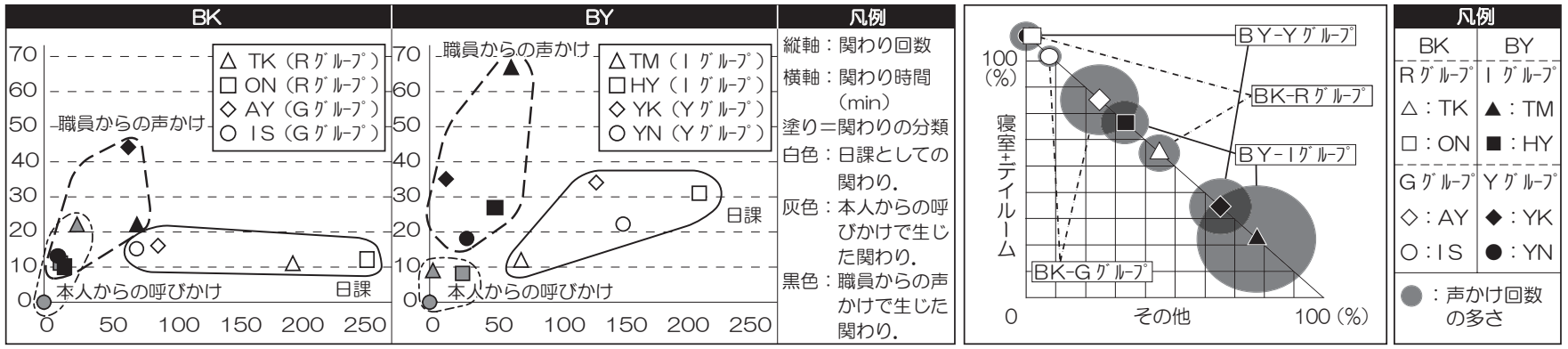

図 12 職員との関わり（回数・時間関係図）

図 13 職員からの声かけが発生する場所の割合と回数 
えることができるので，コミュニケーション能力が低い居住者に比 べて職員との関わり方も異なる.さらに，行動障碍をもち自力で移 動することはできるが，危険の認識が困難な場合など，見守りが必 要となる居住者に対する職員からの声かけは, 頻繁になされている.

関わりの回数と時間の間には, 関わり回数が多いと関わり時間の 総計も長くなるなどの単純な相関関係は見られない。

\section{2 職員からの声かけ}

居住者と職員との関わりをみる時に, 居住者の移動能力やコミュ ニケーション能力によらず，施設の空間的な特性上もつとも差異が 生じるのは，職員からの声かけであると考えられる，例えば，居住 者に対する職員の数が同じであっても，空間数が多くなれば職員の 滞在密度は低くなり, 居住者との居合わせの頻度は低くなるといっ たことが想定されるためである。 そこで, 図 13 に職員からの声かけ が生じた場所の割合と，声かけ回数を示した。なお，ここでは，基
本的な生活場所に加わる空間数の差異と職員からの声かけの様子の 関係を分析するため, 基本的な生活場所と, その他の場所での職員 からの声かけの様子を比較することとし，場所を基本的な生活空間： ［寝室・デイルーム］と，［その他］でわけた，図より，3・4 章で 示した BK・BY での居住者の滞在場所の相違も影響し，BK ではBY よ りも職員との関わりの発生場所が [寝室・デイルーム]に偏っており, BY では分布の幅が BK よりも大きく，居住者による差異が大きいこ とがわかる. 関わり回数の多さと関わりの発生場所の関係を見ると, BK では両者には特に関係が見られない一方, BY では, [その他］の 場所での関わりが多い居住者ほど関わり回数が多い傾向があり, 職 員との関わりの発生の様子が, 関わり場所の面から両施設で異なっ ていることが指摘できる. また, 両施設とも, 移動可能者は移動で きない居住者よりも［寝室・デイルーム］以外での関わりが多いこ とがわかる。

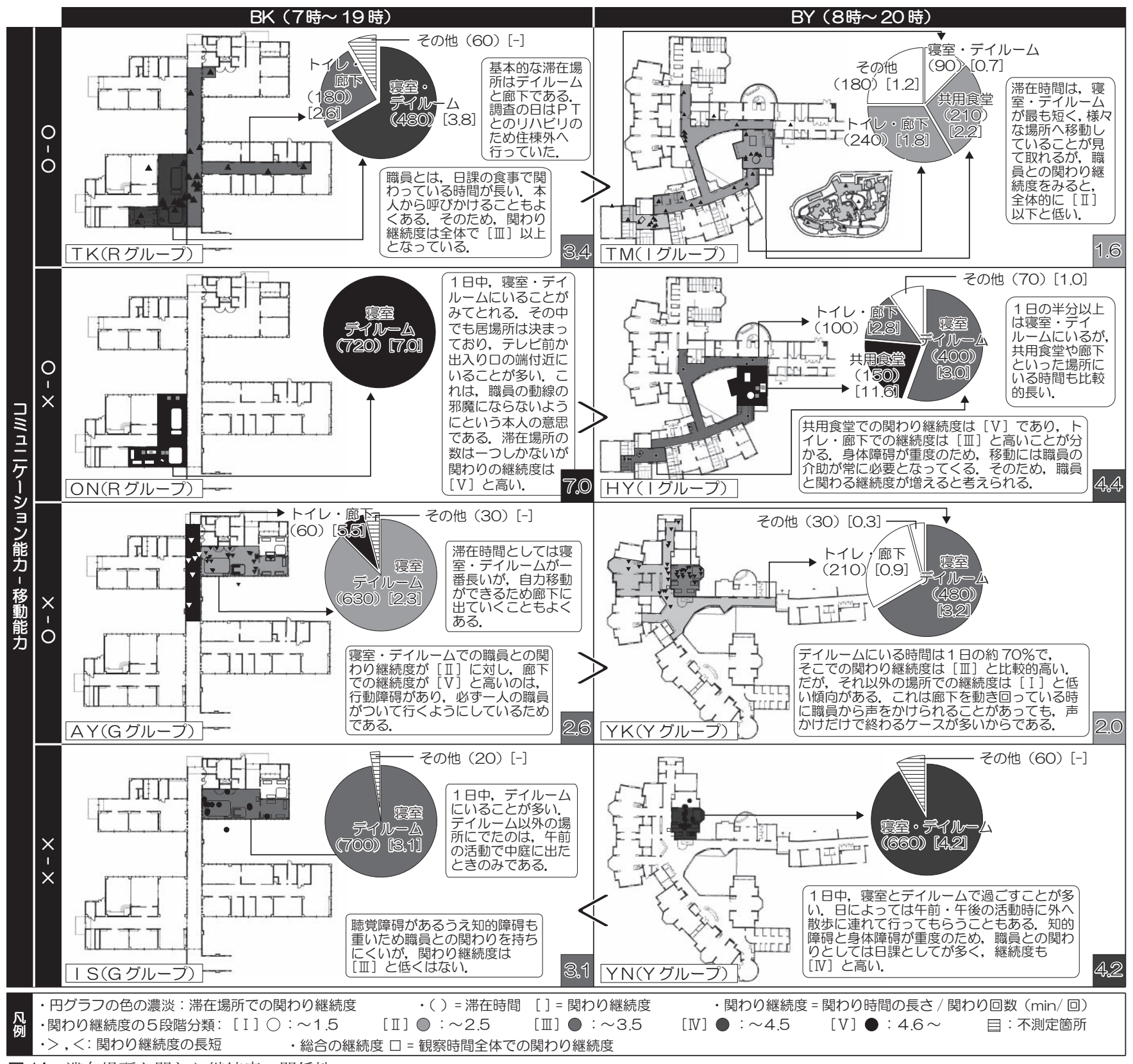

図 14 滞在場所と関わり継続度の関係性 


\section{3 滞在場所と関わり継続性の関係}

図 14 に場所ごとの滞在時間と関わり継続度を示した。滞在場所 をBK では，[寝室・デイルーム］，[トイレ・廊下］，[住棟外・中庭］ と分け, BY では, [寝室・デイルーム], [共用食堂], [トイレ・廊下], [住 棟外・中庭］と分ける。.また, 滞在場所と関わりの継続度の分析対 象時間帯は, BK- 7 時〜 19 時, BY- 8 時〜 20 時と共に 12 時間ずつ, それぞれの施設での主要な活動時間帯とする。また関わり継続度の 算出に関しては，日中活動の時間を除いた個々の居住者と職員との 関わりのみを対象として, 次の式により導き出す.

【関わり継続度 = 関わり時間の長さ/関わり回数 $(\mathrm{min} /$ 回)】

この関わり継続度を, 関わり継続度の分布を参照して注13) 図 14 の凡例に示すように I $-\mathrm{V}$ の 5 段階に分類し，図 14 中に平面図と円 グラフの色調で示した。 円グラフはまた, 日中活動を除く終日の滞 在場所を割合で示している。この図によって個々の滞在場所での関 わり継続度を見ると, 以下のような傾向がある.

観察時間全体での関わり継続度を, 対象者のコミュニケーション 能力と移動能力ごとに比較してみると，コミュニケーションと移動 がともに困難な事例を除いて, BK の方が BY よりも継続度が高く, 1 回の職員との関わりあたりの関わり時間は, BK でより長いと言え る.関わり回数の多さは, 図 12 から BY の方がより少ないというこ とはないが, BY では, 声かけのような短時間の回数が BKよりも多く, 長時間の関わりが比較的少ないといえる. この要因として, BY はBK よりも使われる空間が多いため, これらの場所の移動の時などに自 分のユニットの職員以外の職員からのちょっとした声かけがなされ る場面が観察調查の中でしばしば見られたことがあげられる。また ユニット内に常駐する職員は BK の方が多く, BY ではユニット内で の関わりも BK に比べて短時間である傾向があることが指摘できる.

次に, 個々の滞在場所での関わり継続度を見ると, BK では, コミュ ニケーション・移動能力に関係なく, BY に比べて [寝室+デイルーム] にいる割合が高く, 少数の空間で, 継続度 [II ] 以上の関わりがあ ることがわかる，一方 BY では, 総じて移動できない居住者の関わり 継続度は高く, 移動できる居住者の関わり継続度は低くなる傾向が あり，居住者によって，場所ごとに異なる継続度の関わりが生じて いることがわかる，前節での指摘の通り，BY では，寝室・デイルー ム以外の場所での滞在時間が長い居住者は関わり回数が多い傾向が あり，移動できる居住者はユニット外の複数の場所で，関わりの時 間は短いが声かけなどの短時間の関わりを頻繁に体験していると言 える. また, コミュニケーションが可能な場合, BK では職員との関 わり継続度が居住者の滞在場所すべてで［III］以上であるが，BY で は関わり継続度の低い滞在場所がある. 居住者によって, また滞在 場所によって異なる様相の関わりが発生しているといえる.

以上のように，両施設での空間的特徵が職員とのコミュニケー ションの様相にも差異をもたらしているといえる.

\section{6. まとめ}

本研究では，重症児者施設において，空間構成が異なる小規模生 活単位型療育を実施している 2 施設での居住者の生活様態を比較す ることで, 施設の空間構成の相違が, 施設居住者の滞在場所や移動, 職員との関わりに代表させた居住者の生活様態にどのような影響を
もたらすかを明らかにすることが目的であった。この結果, 本稿で は主に以下の知見を得た。

1) BK と BY 両施設で，移動・コミュニケーションがともに可能 である居住者はユニット外への滞在が多く, 他の居住者は長時間を ユニット内で過ごし, ユニット外に出ることはきわめて少ない.こ の傾向は, BK でより顕著であり, BY では, ユニットと, 自力移動が 可能か否かによって滞在場所が大きく異なる.

2 ) 職員との関わりは，日課をきっかけに発生することが多い. BK では職員との主な関わり場所はすべてユニット内である。一方 BY では，共用食堂がある第 2 住棟の対象者の関わりは，ユニット外の 共用食堂である. また, BY ではユニット外での関わりが多い居住者 ほど職員からの声かけ回数が多い傾向がある.

3) BK では, 移動能力によらず場所の移動頻度の差は小さい。一 方ユニット外での滞在場所がある BY では, 自力移動ができる居住者 ほど移動し，居住者による移動頻度の差が大きい，

4) 自力移動ができないからといって空間利用数が少ないわけで はないが，移動可能者の空間利用数は，全体に移動不可能者よりも 多い。また BK では移動できる居住者でも空間利用数が移動不可能者 と大差なく, 生活上必須となる場所以外の場所に滞在する居住者が 少ない。

5 ) 移動可能な居住者では, 同一空間内での移動頻度は BK の方が BY よりも多いが, 自力移動できない居住者では, 両施設での差は明 らかではない.

6 ) BY では, 移動可能者は同一空間内ではさほど移動をしない. 自力移動ができない居住者にとって, 空間利用数が増えると同一空 間内での移動頻度は減少する傾向にある.

7 ) BK では, 空間利用数が多いと同一空間内での移動頻度も多い. 一方 BY では, 空間利用数が多いと同一空間内での移動頻度も多い居 住者がいない.

8 ）関わり回数の多さは, BK・BY での多宾は単純に言えないが, 関わりの継続度は, BK の方が BY よりも総じて高く, 1 回の職員と の関わりあたりの関わり時間は, BKでより長い.

9 ) BK では, 移動・コミュニケーション能力に関係なく, 少数の 空間で, 比較的継続する関わりがある. 一方 BY では, 総じて移動で きない居住者の関わり継続度は高く, 移動できる居住者の関わり継 続度は低くなる傾向があり, 居住者によって, 場所ごとに異なる継 続度の関わりが生じていることがわかる.

以上から，両施設では様々な点で生活様態に相違があることが指 摘される. 両施設は, 同一法人の運営により, また調查対象者の属 性に差異が生じないように調査対象グループを選定しているため, こうした相違の要因として, 空間構成の相違と, これに伴う生活展 開の相違が影響しているものと推論される. また, 両施設の空間条 件等の相違は，移動可能者にとってより影響が強いといえる.

具体的には，生活上必ず使う場所がユニット内に完結している BK では，生活自体もユニット内で完結していることがわかった，居住 者はユニット内の限られた場所で, 職員からの継続した関わりを受 けながら安定した生活を送っているといえるが，そのなかで，移動 可能者は同一空間内を転々とするなどして過ごしており, 移動可能 者にとっては生活に閉塞感が生じている可能性がある.一方 BY では, 
表 4 各施設の調查対象住棟の利点と不利点

\begin{tabular}{|c|c|c|}
\hline 住棟 & 利点 & 不利点 (課題点) \\
\hline 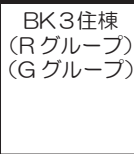 & 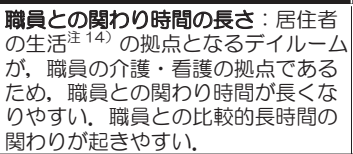 & $\begin{array}{l}\text { 動ける居住者にとっての行動主 15) } \\
\text { 範囲が拡がりにくいこと: 利用でき } \\
\text { る空間が少ないため, 動きたい意思 } \\
\text { がある居住者にとっては落ち着か } \\
\text { ず, 居心地が悪く感じてしま危惧 } \\
\text { がある. }\end{array}$ \\
\hline $\begin{array}{c}\text { BY1 住棟 } \\
\text { (Yグループ) }\end{array}$ & $\begin{array}{l}\text { 生活領域が拡がり得ること（拡大の } \\
\text { 可能性), 滞在場の所選択肢を得や } \\
\text { すいこと: デル仆に生活の } \\
\text { 場, 滞在できる場となるコーすーが } \\
\text { あるため, 職員の誘導によって生活 } \\
\text { の幅が拡がる. }\end{array}$ & $\begin{array}{l}\text { 職員の見守りが可能な, 住棟外部の } \\
\text { 行動場所が確保しにくいこと: 知的 } \\
\text { 障碍が重度の居住者が多いため, 職 } \\
\text { 買からの見守りが常時必要であり, } \\
\text { 移動できる範囲が住棟のブロック内 } \\
\text { と限られている. }\end{array}$ \\
\hline $\begin{array}{l}\text { BY2住棟 } \\
\text { (1グループ) }\end{array}$ & 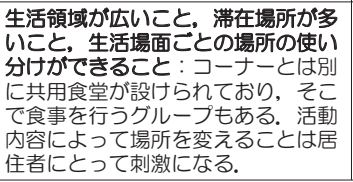 & 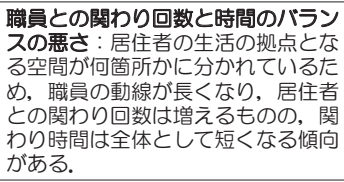 \\
\hline
\end{tabular}

居住者によって滞在場所や職員との関わりの様相に差異が大きく, 特に知的障碍が比較的軽く移動もできる居住者は 1 日の間に複数の 空間に滞在し，しかもそれぞれの場所に安定的な滞在場所をもって いる. またこうした居住者の場合, 職員との関わりの継続度は低く, 声かけなどの短時間の関わりが多い. 総じて, BY の方が BK よりも 生活圈に拡がりがあり，居住者それぞれの個性に即した生活が展開 しているが, 職員との関わりという点では BK の方が BY よりも密で ある. 以上をふまえて各施設の調查対象住棟の利点と不利点を表 4 のようにまとめる.

本稿では, 以上のように空間構成の相違に起因すると思われる両 施設での生活様態の相違を明らかにした。これらの相違は, 空間構 成としてどちらが優れているかという議論ではなく, 居住者像や, 目指寸生活展開によってそれぞれの空間構成に利点あるいは不利点 が生じうることを意味しているものと考える．またこうした施設空 間としての不利点は, 運営面での対応によって克服されうる可能性 もあり, 施設の空間構成について計画するにあたって, その利点と 不利点について認識しつつ, 運営のあり方を含めて検討していくこ とも必要であると考える，たとえばいずれの施設においても，自力 移動が可能であるか否かによらず，施設内での場所づくりや職員の 介助等で生活の場所と人的な関わりが可能な範囲を拡げることで, 個々の居住者の特性に即した生活や，1日の生活に何らかの変化を 与え, 生活の質の向上を図ることができよう.

今後は, こうした視点から人的交流の拡がりや居住者が体験する 生活場面に踏み込んで研究を継続し, 空間構成と居住者の生活様態 の関係，またその課題を克服するハード/ソフト両面での手法につ いて明らかにすることが必要である。

\section{謝辞}

本研究で調查対象とさせて頂いた BK, BY の両施設の皆様におかれ ましては，長期にわたる実習・調査を快く受けいれていただきまし て，心より感謝致します。ここに記して謝辞とさせて頂きます。

注

注 1 ）全国の重症児者施設の現状や傾向については稿を改めて詳しく論ずる が，2008 年 8 月現在での全国の概況についてアンケート調査を実施した結 果, $4 / 51$ 施設のみ生活単位が 10 人以下でユニットケアに取り組んでいる. (全国 119 施設に郵送回答方式でアンケート調查依頼. 51 施設から回答を 得た。回収率：約 $43 \%$ )

注 2 ) 両施設とも， 3 住棟構成. BK では, 1 つの住棟で 32 人〜 37 人, 4 〜 6 グループ構成. BY では, 1 つの住棟で 35 人〜 50 人, 6 グループ構成.
注 3 ) 各住棟の職員と居住者の比率は以下の表を参照とする.

\begin{tabular}{|c|c|c|c|c|c|c|c|}
\hline & \multicolumn{3}{|c|}{ 居住者 } & \multicolumn{3}{|c|}{ 職員 } & 比率 \\
\hline & 長期入居 & 短期入居 & 計 & 介護系 & 生活支援系 & 計 & 居住者：職員 \\
\hline BK第3住棟 & 33 & 3 & 36 & 10 & 23 & 33 & $1: 0.92$ \\
\hline 3Y 第1 住棟 & 47 & 3 & 50 & 26 & 22 & 48 & $1: 0.96$ \\
\hline BY第2住棟 & 48 & 2 & 50 & 24 & 22 & 46 & $1: 0.92$ \\
\hline
\end{tabular}

注 4 ) BK では, 排泄時にトイレに行く居住者は, $25 \%$ （R グループ [ 2/8人 ] • Gグループ [2/8人 $]$ ) であるが，トイレ以外の場所（主に寝室）に行き 排泄行為を行う（おむつ交換を行う）居住者も含めると約 $56 \%$ （R グルー プ [ $6 / 8$ 人 $] \cdot G$ グループ [ $3 / 8$ 人 ] ) が排泄のために場所を移動する. BK の各ユニットにはトイレが 1 つしないため, 1 人の居住者が使用する と, 他の居住者は使用できない. そのため, トイレ以外の場所で排泄を行っ ていると考えられる.よって排泄のためにトイレ以外の場所に移動するこ とは，トイレに行くことと同様の意味に捉えてよいと考えられる。 また， BY では, 排泄のためにトイレに行く人は, 約 $81 \%$ （Y グループ [ $5 / 8$ 人 ]・ I グループ $[8 / 8$ 人 $]$ ) である. それぞれの施設でトイレに行く回数は, 1 日 5 回程度である。

注 5 ） BY のI グループが利用している共用食堂は, 毎日, 朝・昼・晚の 3 食 ともこの場所で食事をとる.

注 6 ) ここでは, 日々の生活領域の最も根幹をな寸範囲として, 「毎日の利用」 が想定される領域を対象とした。このため, 日常生活行為とは, [就寝, 食 事, 排泄] を指す。通常入浴も日常生活の一端を占めるが, 入浴は週 3 回 であり，入浴がある日とない日によって生活のリズムが異なる。本稿では, 入浴のない日を対象とした.

注 7 ）食事場所において, 第 1 住棟のY グループはリビングであるが，第 2 住棟のI グループでは共用食堂であり，場所が異なる。

注 8 ) 移動能力 : 何らかの方法で移動できる能力とする.

コミュニケーション能力：言語でのコミュニケーションができる能力とす る.

注 9 ）調査対象者の選定に際しては，山脇らが明らかにした重症児者の自己 決定的な生活には移動能力とコミュニケーション能力が重要であるという ことを参考にし，移動能力とコミュニケーション能力を軸に，各施設の責 任者とも相談しつつ，こうした能力の相違を比較しやすいと思われる方を 選定した.

注 10）本稿における “関わり”とは，職員が声をかける，または居住者の方 から何らかのサインを出すことによって生じたやりとりのことを指してい る. 介護・看護, 声かけ, 会話などをすべて一括して“関わり”としている.

注 11）移動頻度：図 4 に示すような空間から別の空間へ移ることを移動とし, その回数を表したもの.

注 12) (1)，(2)から，山脇らが指摘した移動能力の差は移動頻度に大きく関わ ることが確認できる、いろいろな空間があることは，移動能力がある人に とっては, より意味深いと推論される.

注 13）関わり継続度：以下に示寸関わり継続度の分布を参照に, I 〜 Vの 5 段階に分類した.

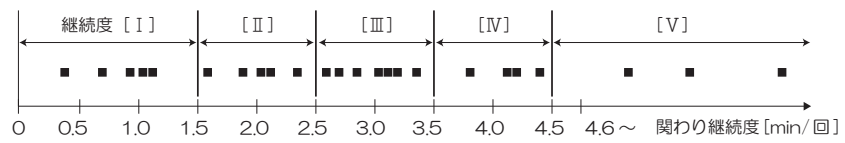

注 14）生活 : 食事・入浴・排泄・日中活動

注 15）行動：「生活」「行為」以外の自由な時間での活動や行為

\section{参考文献}

1) 山脇博紀・菅野實・小野田泰明・坂口大洋 : 重症心身障害児のコミュニケー ション特性からみた居住環境の整備に関する研究, 日本建築学会計画系論 文集，N0.520, PP. 131-138, 1999.6

2 ）山脇博紀・外山義・三浦研：居場所選択にみるユニット型重症心身障害 児施設における入所児の生活展開, 日本建築学会大会学術講演梗概集, E-1 分冊, PP. 167-168, 2001.8

3 ) 山田あすか・上野淳：グループリビング型知的障碍者入所更生施設にお ける居室及び共用空間の設えと入居者の滞在に関する研究, 日本建築学会 計画系論文集，N0. 595，PP. 57-64，2005.9

4 ）永原聖・石井敏・松本啓俊：痴呆性老人の施設形態別にみたケアの実態 に関する解析的考察 - 小規模居住形態の有効性の実証に関する研究 -, 日 本建築学会計画系論文集，N0.514，PP. 79-86，1998.12

5 ) 毛利志保・井上由起子・谷口元 : 小規模生活単位型特別養護老人ホーム におけるケア体制を踏まえた空間特性に関する研究, 日本建築学会計画系 論文集，N0.572，PP. 41-47，2003.10

6 ) 山口健太郎・山田雅之・三浦研・高田光雄 : 介護単位の小規模化が個別 ケアに与える効果 - 既存特別養護老人ホームのユニット化に関する研究 (そ の 1 ） -, 日本建築学会計画系論文集, N0. 587, PP. 33-40, 2005. 1

7 ) 山田あすか・濱洋子・上野淳 : 小規模生活単位型特別養護老人ホームに おける空間構成と入居者の生活様態の関係, 日本建築学会計画系論文集, N0. 629, PP. 1477-1484, 2008. 7

8 ) 江草安彦 監修: 重症心身障害療育マニュアル第 2 版, 医歯薬出版株式 会社，1998.11

9 ) 兵庫重症心身障害児教育研究集会実行委員会 編集 : 重症児教育, 株式 会社クリエイツかもがわ, 2004.8 